\title{
Plasmids from freshwater environments capable of IncQ retrotransfer are diverse and include pQKH54, a new IncP-1 subgroup archetype
}

\begin{abstract}
Correspondence
Christopher M. Thomas

c.m.thomas@bham.ac.uk
\end{abstract}

Received 20 February 2006

Revised 24 May 2006

Accepted 4 June 2006

\author{
Anthony S. Haines, ${ }^{1}$ Parveen Akhtar, ${ }^{1}$ Elton R. Stephens, ${ }^{1}$ Karen Jones, ${ }^{1}$ \\ Christopher M. Thomas, ${ }^{1}$ Caroline D. Perkins, ${ }^{2}$ Jacqueline R. Williams, ${ }^{2}$ \\ Martin J. Day ${ }^{2}$ and John C. Fry ${ }^{2}$ \\ ${ }^{1}$ School of Biosciences, University of Birmingham, Edgbaston, Birmingham B15 2TT, UK \\ ${ }^{2}$ Cardiff School of Biosciences, Cardiff University, PO Box 915, Cardiff CF1 3TL, UK
}

\section{INTRODUCTION}

A range of conjugative plasmids can facilitate the movement of genes in the opposite direction to classical transfer events by a process known as retrotransfer or retromobilization. This process, which was first observed in homologous and intergeneric matings using the IncP-1 plasmid pULB113 (Mergeay et al., 1987), enables capture of chromosomal genes or non-conjugative plasmids by the host bearing the conjugative plasmid. The mechanism of this process, whether it occurs as an indirect consequence of conjugation or is a distinct genetically determined process, has proved controversial (Blanco et al., 1991; Top et al., 1992; Heinemann \& Ankenbauer, 1993a, b; Perkins et al., 1994; Ramos-González et al., 1994; Szpirer et al., 1999), but for IncP-1 plasmid RK2 it has been demonstrated that the plasmid must transfer into the recipient before it can mobilize the captured plasmid back to the donor (Sia et al.,

The GenBank/EMBL/DDBJ accession number for the nucleotide sequence of pQKH54 is AM157767.

A supplementary table of biologically relevant reading frames identified in the pOKH54 sequence is available with the online version of this paper.
1996). Consistent with this model of retromobilization involving two unidirectional steps, it has been proposed that low surface exclusion is important in the mobilizing plasmid (Szpirer et al., 1999), presumably because strong surface exclusion would disrupt mating pairs before transfer back from the recipient had occurred. In addition it seems likely that retromobilization specificity is determined by the VirD/TraG-like coupling proteins (Gomis-Ruth et al., 2002). However, it is not clear how widespread this ability is among uncharacterized plasmids and whether this phenomenon is environmentally important.

Attempts have also been made to link retrotransfer to certain plasmid incompatibility groups. So far, retrotransfer has been demonstrated for the plasmid groups IncP-1 (Mergeay et al., 1987; Powell et al., 1989; Blanco et al., 1991; Heinemann \& Ankenbauer, 1993a, b; Smit et al., 1993; Perkins et al., 1994; Hill et al., 1995; Top et al., 1995), IncM and IncN (Thiry et al., 1984; Mergeay et al., 1985), IncF and IncW (Heinemann \& Ankenbauer, 1993a, b; Wlodarczyk \& Piechucka, 1995) and IncP-9 (Ramos-González et al., 1994; Ronchel et al., 2000) in a variety of different bacteria as well as some plasmids that do not belong to well-established groups (Szpirer et al., 1999). The majority of these groups 
are recognized as broad host range, possessing mechanisms which allow them to transfer extensively (Mergeay et al., 1990; Szpirer et al., 1999). IncP-1 plasmids have been specifically implicated in retrotransfer and can transfer to an exceptionally wide range of cell types, showing DNA mobilization to Gram-positive bacteria (Trieu-Cuot et al., 1987), cyanobacteria (Kreps et al., 1990) and yeasts (Heinemann \& Sprague, 1989).

Allocating plasmids to specific incompatibility groups often proves difficult. Traditional methods of testing are laborious and rely on transfer of a known incompatibility group plasmid into the strain bearing the plasmid under study and checking for displacement of either plasmid (Stanisich, 1988). Displacement occurs as a consequence of two plasmids sharing similar replication control and/or partitioning systems (Kittell \& Helinski, 1993; Novick, 1987). So far about 30 incompatibility groups are known for plasmids studied in Enterobacteriaceae (Jacob, 1977) and 14 in Pseudomonas species (Boronin, 1992). Specific DNA sequences corresponding to genes involved in replication control have been identified for the Enterobacteriaceae plasmid groups (Couturier et al., 1988; Davey et al., 1984) and have proved useful in characterizing plasmids of medical importance by replicon typing.

Few studies have assessed the potential of plasmids from natural environments to carry out retrotransfer. However, some retrotransfer-proficient plasmids showing broad-host-range characteristics have been isolated from natural sources (Hill et al., 1992). In this study we aimed to determine whether plasmids capable of retrotransfer within an aquatic environment are limited to incompatibility groups known already to be capable of retrotransfer. The only known plasmid group identified was the IncP-1 family, although members of this group represented a minority of the plasmids tested. One plasmid, pQKH54, which appeared to be IncP-1 by some tests but not others was characterized by determining its complete genome sequence and proved to belong to a new subgroup of this ubiquitous plasmid family, which we have designated IncP- $1 \gamma$.

\section{METHODS}

Bacterial strains and plasmids. Bacterial strains and plasmids used in this study are listed in Table 1 and Table 2 respectively. Strains were maintained on nutrient agar (NA) or L agar (LA) and grown in nutrient broth (NB) or Luria Broth (LB) containing the appropriate selective markers (Sambrook et al., 1989). Other media used are mentioned in context. Supplements were as follows: nalidixic acid (Nal), $200 \mu \mathrm{g} \mathrm{ml}^{-1}$; rifampicin (Rif), $100 \mu \mathrm{g} \mathrm{ml}^{-1}$; streptomycin $(\mathrm{Sm}), 1000 \mu \mathrm{g} \mathrm{ml}^{-1}$; kanamycin $(\mathrm{Km}), 50 \mu \mathrm{g} \mathrm{ml}^{-1}$; tetracycline (Tc), $40 \mu \mathrm{g} \mathrm{ml}^{-1}$; mercuric chloride $(\mathrm{Hg}), 27 \cdot 5 \mu \mathrm{g} \mathrm{ml}^{-1}$ in nutrient agar or $13.5 \mu \mathrm{g} \mathrm{ml}^{-1}$ in casein hydrolysate medium. An exception was matings involving Cytophaga heparina, where $\mathrm{Hg}$ concentrations of $10 \mu \mathrm{g} \mathrm{ml}^{-1}$ were used.

Purification of plasmid DNA and restriction analysis. Plasmids of $>100 \mathrm{~kb}$ were extracted by the method of Wheatcroft \& Williams (1981). For smaller plasmids the alkaline SDS procedure

Table 1. Bacterial strains

Abbreviations: $\mathrm{Sm}^{\mathrm{r}}$, streptomycin resistant; $\mathrm{Nal}^{\mathrm{r}}$, nalidixic acid resistant; Rif ${ }^{\mathrm{r}}$, rifampicin resistant; $\mathrm{Sp}^{\mathrm{r}}$, spectinomycin resistant; Trp, tryptophan; Ilv, isoleucine, leucine, valine; Met, methionine; 3CB, 3-chlorobenzoate.

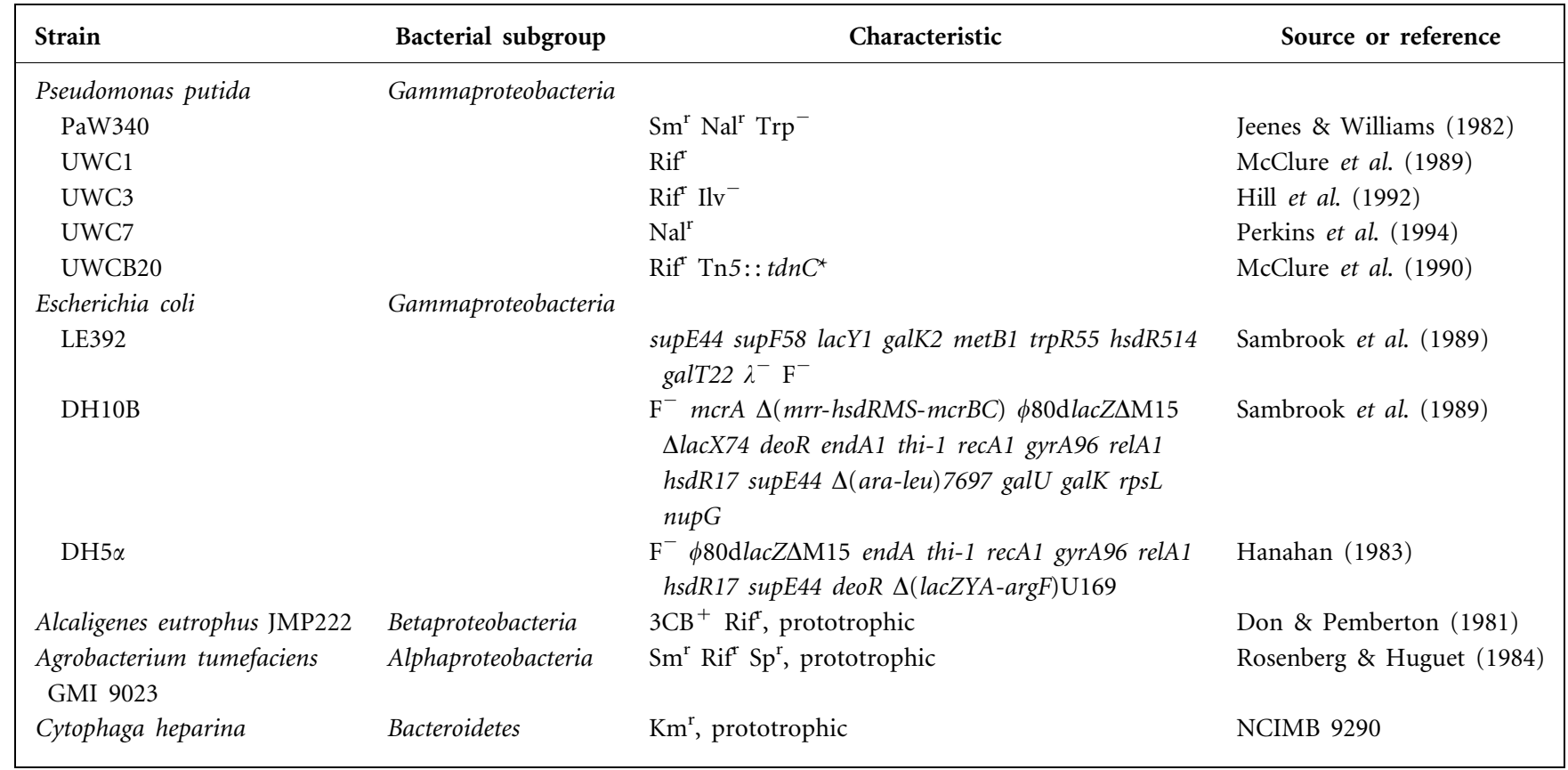

*Produces a yellow product, 2-hydroxymuconic semialdehyde, on spraying with catechol. 


\section{Table 2. Plasmids}

Abbreviations: ND, not determined; Pn, penicillin; Ap, ampicillin; Tc, tetracycline; Km, kanamycin; Hg, mercury; Tm, trimethoprim; Sm, streptomycin; Sul, sulphonamide; $\mathrm{Tra}^{+}$, conjugative; $\mathrm{Mob}^{+}$, mobilizable; R, rifampicin resistance mutant of specified strain. Exogenous isolation recipients: UWC1, UWC3, Pseudomonas putida; PAO2002R, PAO348R, Pseudomonas aeruginosa; LE392R, Escherichia coli. Only those strains actually used in this study, as opposed to during the previously described isolation of these plasmids, are listed in Table 1.

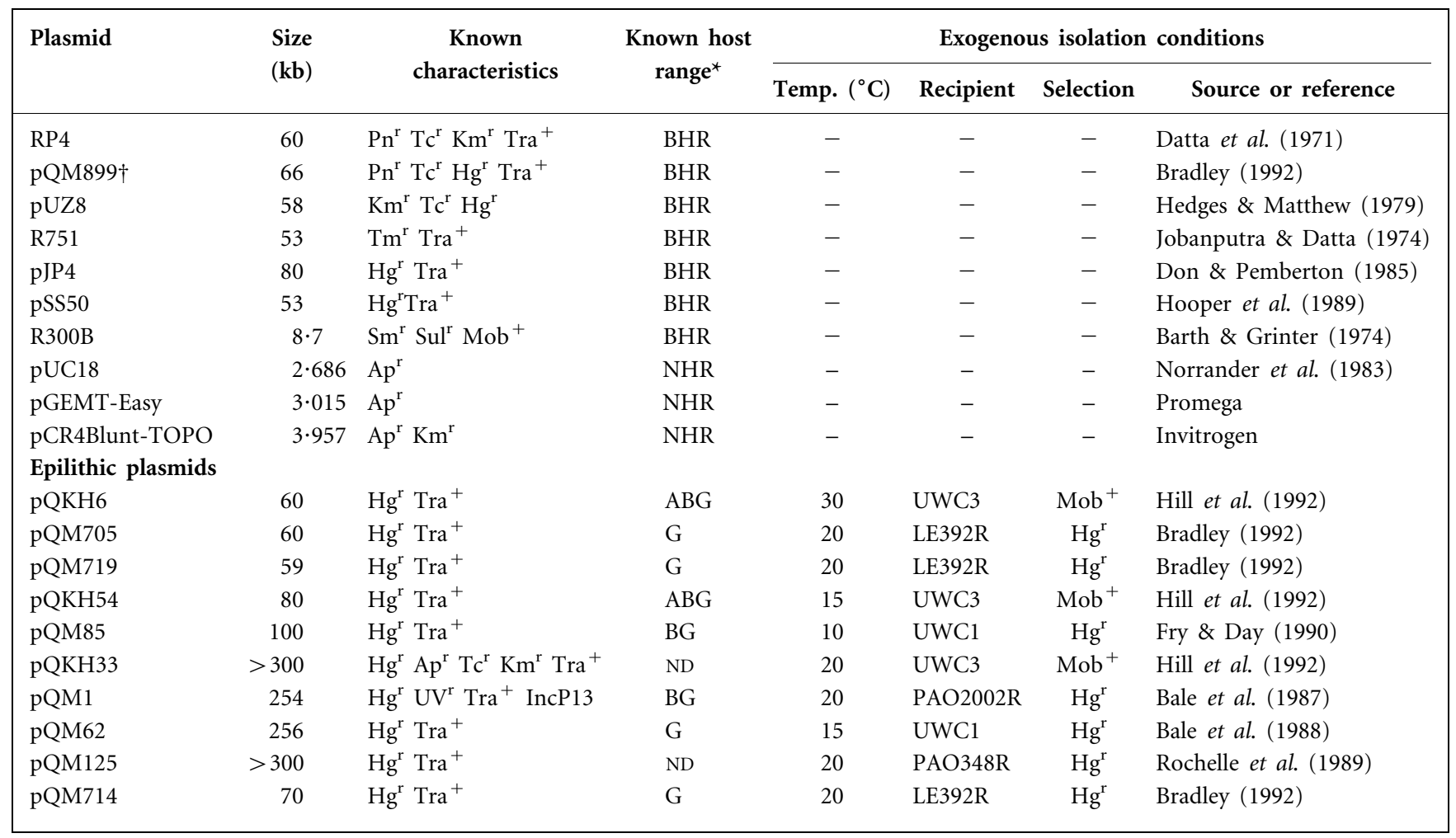

${ }^{\star} 16 \mathrm{~S}$ rRNA classification subgroups of Proteobacteria to which plasmids can transfer. BHR, broad host range, can be transferred to a wide range of Gram-negative bacteria $(\mathrm{A}=\alpha, \mathrm{B}=\beta$, and $\mathrm{G}=\gamma 16 \mathrm{~S}$ rRNA subgroups of the Proteobacteria listed in Table 1). ND, Not determined.

$\dagger \mathrm{Hg}^{\mathrm{r}}$ transposon $\mathrm{Tn} 501$ inserted into the $\mathrm{Km}^{\mathrm{r}}$ gene of RP4 to produce plasmid pQM899.

was used (Birnboim \& Doly, 1979; Kado \& Liu, 1981). Further purification was by $\mathrm{CsCl}$ gradient for larger-scale preparations (Sambrook et al., 1989). Both standard and pulsed-field gel electrophoresis (PGFE) were carried out to obtain accurate size measurements for restriction bands. PFGE was performed by the CHEF DR II system with $0.5 \times \mathrm{TBE}$ (Sambrook et al., 1989) at $8{ }^{\circ} \mathrm{C}$ using $1 \cdot 2 \%$ pulsed-field-grade agarose gels (Bio-Rad pulsed-field certified). Gels were run for $18 \mathrm{~h}, 150 \mathrm{~V}$ at $4 \mathrm{~s}$ pulse times, followed by $6 \mathrm{~h}, 110 \mathrm{~V}$ at $2 \cdot 5 \mathrm{~s}$ pulse times. Ethidium-bromide-stained gels were scanned using a scanning densitometer and similarity between plasmid profiles was calculated by matching of peak positions using GelManager for Windows (BioSystematica). Dendrogram plots were produced as a result of clustering by UPGMA (unweighted pair group method using averages) on SphI digests of each plasmid, performed in buffers according to the manufacturer's instructions. The multiple regression method (Rochelle et al., 1985) was used to calculate fragment sizes based on migration of known molecular mass markers.

Conjugative transfer. Overnight NB cultures of donor $(100 \mu \mathrm{l})$ and recipient $(1000 \mu \mathrm{l})$ strains were mixed and mating allowed to proceed on a $0.45 \mu \mathrm{m}$ cellulose nitrate filter which was placed on a NA plate for $24 \mathrm{~h}$ at $20^{\circ} \mathrm{C}$ or $30^{\circ} \mathrm{C}$. The bacteria were then resuspended in $2-5 \mathrm{ml} 1 / 10 \times \mathrm{NB}$ and c.f.u. enumerated by standard techniques on NA at $30^{\circ} \mathrm{C}$ containing appropriate antibiotics (Bale et al., 1987). Frequencies of conjugal transfer and retrotransfer were determined from isogenic matings between Pseudomonas putida UWCB20, bearing the conjugative plasmids, and UWC7(R300B). Transconjugants were selected on $\mathrm{NA}+\mathrm{Nal}+\mathrm{Sm}+\mathrm{Hg}$ and retrotransconjugants on $\mathrm{NA}+\mathrm{Rif}+\mathrm{Sm}+\mathrm{Hg}$. In mobilization UWC7 was the donor, containing both the conjugative plasmid and R300B. Transfer of R300B to UWCB20 was selected on NA+Rif + Sm. For plasmid host-range studies, PaW340 bearing the $\mathrm{Hg}^{\mathrm{r}}$ plasmid was mixed with a range of recipients. Casein hydrolysate medium (Oxoid L41), which is deficient in tryptophan, was used to select against $\mathrm{PaW} 340$, with additions of $\mathrm{Hg}$ to select for transconjugants. Donors were enumerated on Pseudomonas selective medium (Oxoid CM559) plus cetrimide and nalidixic acid (Oxoid CN selective supplement SR102) and Hg. Representative colonies of putative transconjugants and retrotransconjugants were checked for the relevant plasmids. Transfer frequencies were compared by analysis of variance using $\log _{10}$-transformed data to ensure homogeneity of variance and normality of error distribution. All means are expressed as geometric means and transfer frequencies as transconjugants per recipient. Mean values were compared by least significant difference (LSD) or minimum significant difference (MSD), using the TukeyKramer test for the latter, as appropriate.

Probes used in hybridization studies. Probes for replicon typing as defined by Couturier et al. (1988) were prepared by digestion 
of purified plasmid DNA with appropriate restriction enzymes, separated by gel electrophoresis and eluted from low-melting agarose using the Geneclean II kit (Bio Inc.). Probes for the following incompatibility groups were used: IncY (1245 bp), IncT (304 bp), IncX ( $942 \mathrm{bp})$, IncL/M (800 bp), IncU (950), IncQ (357 bp), IncFIA (917 bp), IncFIB (1202 bp), IncB/O (1600 bp), rep9 (539 bp), IncHI1 (2250 bp), IncHI2 (1800 bp) and IncP (750 bp). Probes were denatured in a boiling water bath for $10 \mathrm{~min}$ and labelled by random priming using dioxigenin (DIG)-dUTP (Boehringer Mannheim) according to the manufacturer's instructions. Additional probes were prepared from the plasmids R751 and pQKH6. R751 (Thorsted et al., 1998) DNA was digested with PstI, producing five fragments corresponding to: (i) Tra2/Tra3/trfA region; (ii) Tra1/ oriT/primase; (iii) Tn5090/404, encoding trimethoprim resistance; (iv) $\operatorname{oriV} / \mathrm{Tn} 4321$; and (v) korA/korB. These were separated by gel electrophoresis and purified as specified using the Glassmax DNA Isolation Spin Cartridge system (Gibco-BRL). As Tn4321 has shown some homology to the mercury-resistance transposon Tn501 it was separated from the oriV fragment by digestion with EcoRI and purification of the two smallest fragments. Plasmid pQKH6 DNA was digested with EcoRI and the largest six fragments were separated by the same technique. These probes were denatured as above and labelled with ${ }^{32} \mathrm{P}$ using Amersham Multiprime according to the manufacturer's instructions. After labelling, unincorporated ${ }^{32} \mathrm{P}$ was removed using Sephadex G50 columns (Sambrook et al., 1989).

Southern blotting and colony hybridization. Extracted plasmid DNA was digested with EcoRI and separated by gel electrophoresis with appropriate replicon controls. Chromosomal DNA of the plasmid host strain was extracted (Austubel et al., 1989) and included to show any background hybridization. Gels were washed and blotted overnight onto nylon membrane (Hybond-N, Amersham) using standard procedures (Sambrook et al., 1989). DNA was fixed by UV irradiation. Membranes were hybridized with DIG-labelled incompatibility probes following the Boehringer Mannheim DIG Nucleic Acid Detection kit instructions. The chemiluminescent detection technique was carried out using Lumigen PPD. Membranes were exposed to X-ray film at room temperature for $30 \mathrm{~min}$ to $3 \mathrm{~h}$. For colony hybridization NB cultures were used to inoculate circular membranes on tryptone-based medium, incubated overnight at $30{ }^{\circ} \mathrm{C}$; then the cells were lysed and the DNA was denatured, neutralized and fixed by standard techniques (Sambrook et al., 1989). After washing and prehybridization, ${ }^{32} \mathrm{P}$-labelled probes were used to detect related sequences and signals detected by exposure to X-ray film.

PCR amplification and sequencing of selected IncP-1 regions. Degenerate oligonucleotide primers for IncP-1 control regions were designed previously (Thomas \& Thorsted, 1994). A $241 \mathrm{bp} \operatorname{trfA}$ product (based on plasmid RK2) was expected using the forward primer 5'-CGA AAT TCR TRT GGG AGA AGTA-3' and reverse primer $5^{\prime}$-CGY TTG CAA TGC ACC AGG TC-3'. For the korA gene, a 294 bp (based on RK2) sequence was amplified by the forward primer 5'-ATG AAG AAA CGG CTN ACC GA-3' and reverse primer $5^{\prime}$-TTC CTG TTT YYT CTT GGC GTC-3'. All primer sequences were compared with GenBank nucleotide sequence data for possible homologies with other non-target sequences. Total DNA extracts were from $1.5 \mathrm{ml}$ overnight cultures as described by Austubel et al. (1989). Amplification and analysis of products used standard procedures (Sambrook et al., 1989). Products were sequenced directly using the PCR primers or cloned into pGEMTEasy and then at least three clones were sequenced from universal primers to eliminate errors that might have occurred during amplification.

IncP-1 incompatibility testing. Incompatibility tests were performed in $P$. putida strains. Transfer frequencies into plasmidbearing bacteria at $30^{\circ} \mathrm{C}$ for both RP4 and the mercury-resistance plasmids were determined as described above, selecting for the incoming plasmid only (Stanisich, 1988). After overnight incubation, four colonies were removed from each of the transconjugant plates, either $\mathrm{NA}+\mathrm{Rif}+\mathrm{Km}$ in the case of $\mathrm{RP} 4$ transfer or $\mathrm{NA}+\mathrm{Sm}+\mathrm{Hg}$ for mercury-resistance plasmid transfer. Cells were resuspended in $2 \mathrm{ml} 1 / 10 \times \mathrm{NB}$, and $40 \mu \mathrm{l}$ aliquots of each colony suspension were pipetted into 48 wells of a microtitre plate followed by replica plating to NA plates and separate NA plates containing individual and both selective markers. After overnight incubation at $30^{\circ} \mathrm{C}$ replica plating from growth on NA plates was repeated to determine if growth in non-selective conditions would allow the plasmids to segregate. This was repeated to give over 100 generations of unselected growth. Failure to grow on one or other of the selective plates then indicated incompatible plasmids. DNA was regularly extracted and checked for the correct plasmids and absence of interplasmid recombination. To differentiate surface exclusion effects from true incompatibility, control matings were performed with RP4 and mercury-resistance plasmids into plasmidless recipients of PaW340 or UWCB20. Additional controls were performed by mating known IncP-1 plasmids together and examining the degree of segregation.

Sequencing of pQKH54 and sequence accession number. Subclone libraries of pQKH54 in pUC18 vector were initially generated by cloning SphI fragments, and partial TaqI or Sau3AI digests of the two large SphI fragments. These were sequenced using an ABI373 automated sequencer. Later, subclones were generated using randomly sheared fragments with the TOPO Shotgun Subcloning kit from Invitrogen, using an ABI3700 sequencer. Finishing reads used custom primers on clones or PCR products. A few PCR products were cloned using the Promega pGEM-T Easy vector system. The sequence was produced and assembled using the Phred/Phrap/ Consed package (Ewing \& Green, 1998; Ewing et al., 1998; Gordon et al., 1998, 2001). Analysis and annotation of the sequence used Artemis and ACT (Rutherford et al., 2000) and WU-BLAST2 (http:// blast.wustl.edu/). The nucleotide sequence of pQKH54 has been submitted to the EMBL database (GenBank/EMBL/DDBJ accession no. AM157767). After consultation with the IS database in Toulouse, France (http://www-is.biotoul.fr/), the two new IS elements identified in the DNA sequence have been designated ISUnCu3 (position 13002 to 15597 in the sequence) and ISUnCu4 (position 39749 to 40861 in the sequence) because the identity of the original bacterial host for the plasmid was not known and uncultured.

Construction of phylogenetic tree. To generate the phylogenetic tree for IncP-1 plasmids, protein sequences were aligned using PILEUP (Wisconsin Package, Devereux et al., 1984) and the alignments concatenated. A neighbour-joining tree was generated using CLUSTALX, with gaps excluded and correction for multiple substitutions.

\section{RESULTS}

\section{Retrotransfer matings}

Conjugation frequencies of all the plasmids used in this study were relatively high, ranging from about $10^{\circ}$ to $10^{-3}$ transconjugants per recipient (Table 3). Five of the nine plasmids isolated from epilithon showed significant retrotransfer frequencies, ranging from $2 \cdot 1 \times 10^{-4}$ to $1 \cdot 8 \times 10^{-5}$, which were generally $2-3$ orders of magnitude lower than the respective conjugation frequencies. The highest retrotransfer frequency detected among the plasmids studied $\left(3.6 \times 10^{-3}\right)$ was shown by the IncP-1 $\beta$ plasmid pSS50, which was $15-30$ fold higher than the epilithic plasmids pQKH6, pQM705 and pQM719. For plasmids pQM1, 
Table 3. Summary of characteristics of plasmids studied in this work

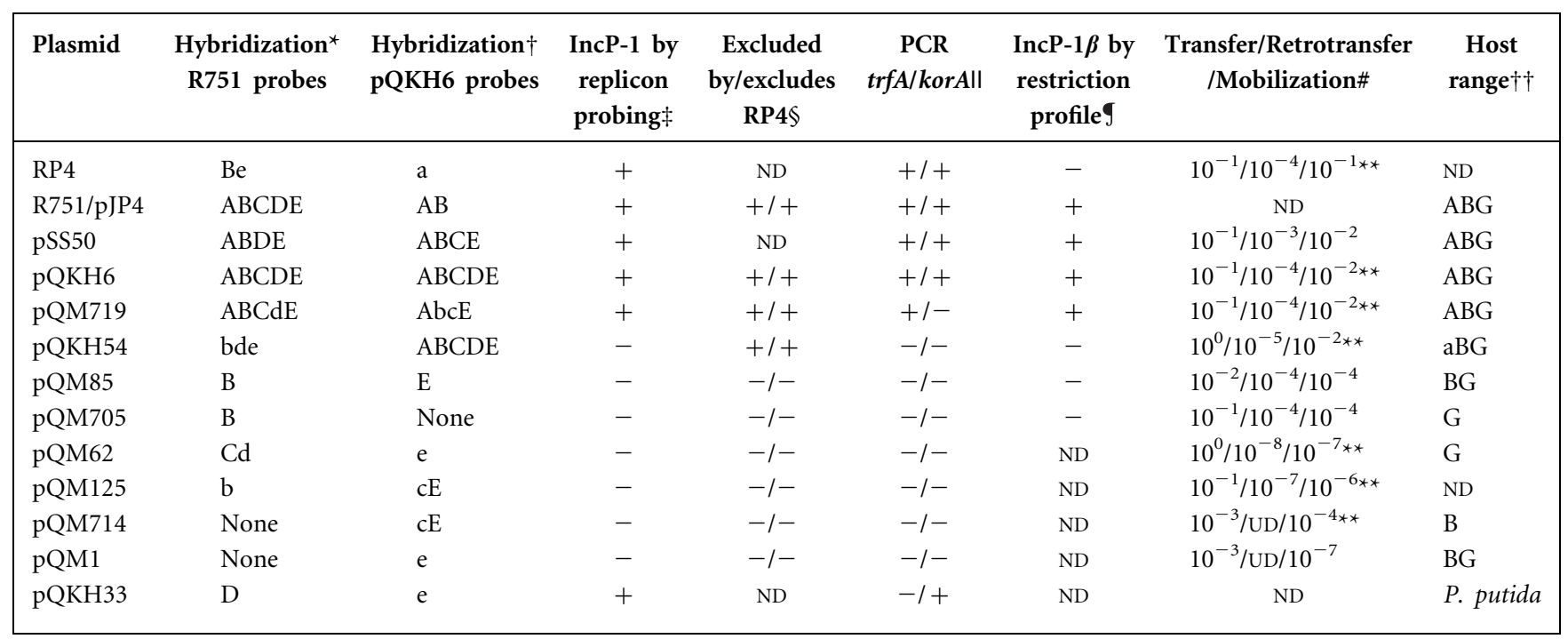

ND, Not done; UD, undetectable.

${ }^{\star}$ R751 Pst probes: A, trb-trfA; B, tra-oriT; C, Tn402; D, korAB; and E, oriV. Upper-case letter means strong hybridization; lower-case letter means weak hybridization.

$\dagger$ pQKH6 PstI probes: A, $38 \cdot 4 \mathrm{~kb} ; \mathrm{B}, 10 \cdot 1 \mathrm{~kb} ; \mathrm{C}, 7 \cdot 0 \mathrm{~kb} ; \mathrm{D}, 3 \cdot 1 \mathrm{~kb} ; \mathrm{E}, 2 \cdot 8 / 2 \cdot 7 \mathrm{~kb}$. Upper-case letter means strong hybridization; lower-case letter means weak hybridization.

$\$$ Hybrization was performed with all the replicon probes described in Methods.

\$IncP-1 incompatibility was assessed by determining (a) whether the presence of RP4 reduced the ability of test plasmids to transfer into PaW340 or (b) or whether the presence of the test plasmid reduced the ability of RP4 to transfer into PaW340. Results are means from replicate matings $(n=2)$. Two-way or one-way ANOVA of transfer frequencies showed significant difference between plasmid $(P<0 \cdot 001)$ and transfer mechanism $(P<0 \cdot 001)$.

IIPCR was performed as described in Methods.

S SphI digestion was carried out as described in the text.

\#All plasmids showed a significant difference between conjugation and retrotransfer frequencies. UWC7(R300B) is classified as the donor strain in retrotransfer mating. ${ }^{* *}$ Indicates a significant difference between the mobilization and retrotransfer frequencies by MSD comparisons.

$\dagger \dagger$ Host range is indicated in the same way as in Table 2. Upper-case letters are used when tested species/strains of that group could receive the plasmid; lower-case letters indicate that transfer frequency into the test strain for that group is significantly reduced. The host range of RP4 was not tested in this study.

pQM62, pQM125 and pQM714, retrotransfer was either undetectable or was just within the limits of detection. All plasmids able to retrotransfer well (at frequencies $>10^{-5}$ ) could also mobilize R300B at frequencies of $>10^{-4}$. Plasmids showing low or undetectable retrotransfer generally had a lower mobilization frequency. An exception was pQM714, which showed similar conjugation and mobilization frequencies but retrotransfer could not be detected.

\section{Plasmid host range}

Host range was tested using $P$. putida PaW340 as donor against the various representative species listed in Table 1 as recipients: Escherichia coli, Alcaligenes eutrophus, Agrobacterium tumefaciens and Cytophaga heparina. Transfer to the C. heparina strain could not be detected for any of the plasmids tested (Table 3). However, the RP4 derivative plasmid $\mathrm{PQM} 899$ and the IncP-1 $\beta$ plasmids showed a broad host range, being transferred and maintained in all subgroups of the Proteobacteria. Epilithic plasmids pQKH6 and pQM719 showed a pattern of transfer similar to that of the IncP-1 $\beta$ plasmids pJP4 and pSS50, with higher transfer frequencies to A. tumefaciens. The transfer frequency of pQKH54 was somewhat lower to this alphaproteobacterial species but high transfer frequencies, as shown by pQKH6 and pQM719, were detected to the gammaand betaproteobacteria subgroups. The remaining plasmid tested, pQKH33, only showed a higher transfer frequency to $P$. putida, with transfer to the other strains at or below the limit of detection.

\section{Classification of plasmids by hybridization with labelled probes}

The only replicon probe that gave a positive signal was that for IncP-1, which showed strong Southern hybridization with plasmids pQKH6, pQM719 and pQKH33 at both high and low stringency using RP4 as a positive control (Table 3). No other probes reacted with any of the plasmids under study, even at low stringency, with the probes for the 
broad-host-range plasmid groups IncN, IncW and IncQ. Plasmid pQM1 has previously been shown to belong to the IncP-13 group of the pseudomonads (Bale et al., 1988) so is unlikely to produce a signal by $E$. coli replicon typing.

Plasmids belonging to the IncP-1 $\beta$ subgroup have previously been differentiated from the IncP- $1 \alpha$ subgroup based on characteristic SphI fragment pattern (Burlage et al., 1990). After SphI digestion a number of identical bands were observed between pQKH6 and pQM719 and the IncP-1 $\beta$ plasmids R751 and pSS50 (data not shown), amounting to a similarity of $50-60 \%$ as indicated in the dendrogram in Fig. 1, which shows just those plasmids that we suspected of being IncP-1 and an outlier, pQM705. RP4, which belongs to the IncP- $1 \alpha$ subgroup, did not show these characteristic fragments, indicating a lack of similarity of pQKH6 and pQM719 to the IncP- $1 \alpha$ subgroup. Plasmid pQKH33 was not examined because it was much larger than the other plasmids $(>300 \mathrm{~kb})$ but additional resistance markers it carries to Ap, Tc and $\mathrm{Km}$ are common to the IncP- $1 \alpha$ subgroup and suggest that it may belong to this group. No significant similarities were observed in the $S p h I$ digestion patterns of pQKH54, pQM85, pQM705 and the known IncP- $1 \beta$ plasmids.

All the plasmids were probed with the fragments from R751 and pQKH6 (Table 3). As expected from the results above, pSS50, pQKH6 and pQM719 hybridized with almost all of the R751 fragments. Regions of common homology were shown for the fragments containing the Tral and oriV

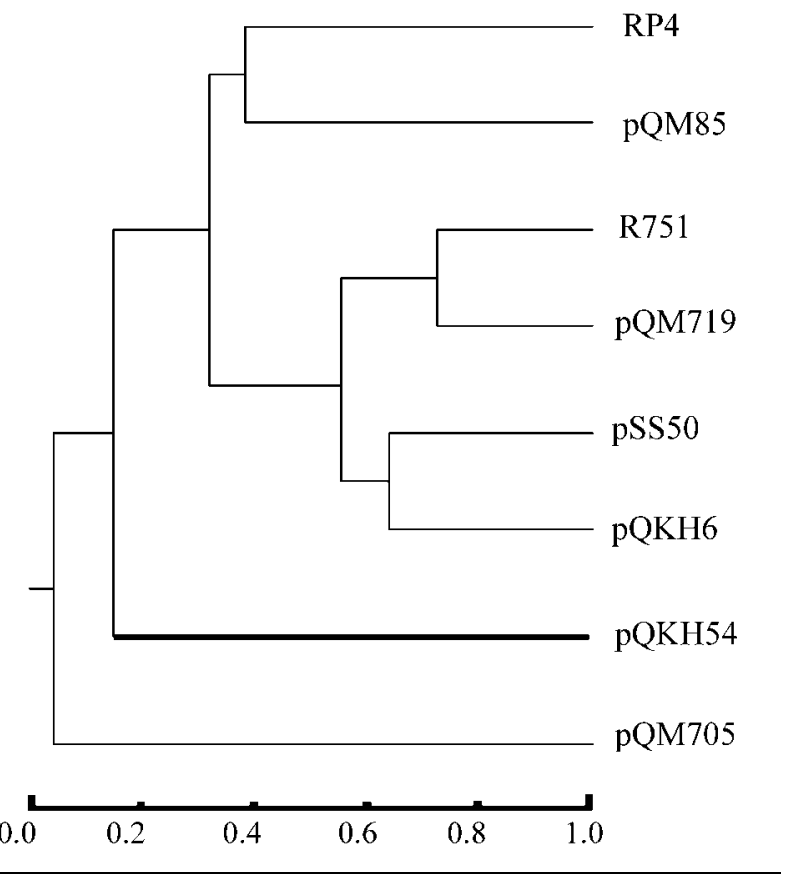

Fig. 1. Dendrogram showing degree of similarity of various plasmids isolated from the epilithon to the IncP-1 $\beta$ plasmids R751 and pSS50 based on the similarity of their restriction patterns after digestion with Sphl. See Methods for details. regions of the different IncP-1 subgroup plasmids RP4 and R751. Of the remaining plasmids only RP4, pQKH54 and pQM62 hybridized strongly with more than one R751 fragment. Plasmids pQM719 and pSS50 also showed a high degree of similarity with the majority of pQKH6 fragments, all of which hybridized to pQKH54. The other epilithic plasmids failed to hybridize with most of the pQKH6 fragments with the exception of the smallest two fragments (5/6). Hybridization of these latter fragments with 9 out of 10 (now including pQKH33) epilithic plasmids and pNMM1 indicated that they encode mercury-resistance genes possessing some homology to Tn501 present on this vector; such genes are widespread and abundant in the environment (Barkay et al., 2003).

\section{IncP-1 incompatibility testing}

Since the only group identified by hybridization is IncP-1 we determined whether this genetic relatedness was manifest as classical incompatibility. Transfer of the epilithic plasmids to PaW340(RP4) identified three, pQKH6, pQM719 and $\mathrm{pQKH} 54$, which could displace RP4 (Table 3). Reduction in transfer due to surface exclusion was also exerting an effect, as transfer of these plasmids to a plasmidless PaW340 recipient was up to 250 -fold higher. As results for the IncP-1 plasmid pJP4 were very similar, pQKH6, pQM719 and pQKH54 were classified as IncP-1 plasmids by this approach. The other plasmids showed no sign of incompatibility to RP4 in this direction although a small degree of surface exclusion was detected for pQM1 and pQM125. Displacement of the epilithic plasmids by RP4 (Table 3) only identified one plasmid, pQKH6, as belonging to the IncP-1 group. Plasmids pQM1, pQM62, pQM125 and pQM714 were again clearly compatible. For the remaining plasmids, pQM705, pQM719, pQKH54 and pQM85, it took some time before a compatible coexistent relationship could be established and both plasmids were clearly visible with no signs of cointegrate formation after extraction and electrophoresis. This suggested a degree of similarity between the replication control genes of these plasmids. Unfortunately pQKH33 could not be tested by this procedure due to its additional markers, Ap, Tc and $\mathrm{Km}$, which prevented selection for RP4.

\section{PCR using trfA and korA primers}

PCR amplification using the $\operatorname{trf} A$ primers was detected in only 2 out of 10 (including pQKH33) of the plasmids isolated from epilithon (Table 3). A $241 \mathrm{bp}$ product was obtained for plasmid controls from the IncP- $1 \alpha$ group, RP4 and pUZ8, and the IncP-1 $\beta$ subgroup, R751, pSS50. A product of the same size was detected for plasmids PQKH6 and pQM719 but not for any of the other plasmids under study. Amplification using the korA primers again resulted in two plasmids producing a similar sized product to the controls, namely pQKH6 and pQKH33. Plasmid pQM719 showed no product, supporting results of colony hybridization with the korA/korB R751 probe, which gave only a weak signal, whereas $\mathrm{pQKH} 33$ gave a strong hybrization signal 
with this probe and a korA PCR product (Table 3 ). The origin of the PCR products for trfA and korA products from R751, pSS50 and pQKH6 was confirmed by sequencing. Sequence alignment showed that pSS50 and pQKH6 were indistinguishable on this basis and that their closest sequenced IncP-1 $\beta$ relative was pJP4 (Smith \& Thomas, 1987; Trefault et al., 2004), to which they showed $>99 \%$ identity, whereas they were clearly different from R751, as expected from the described diversity for this IncP-1 subgroup (Droge et al., 2000).

\section{DNA sequencing and the IncP-1 backbone of pQKH54}

The results described above indicated that pQKH54 is related to IncP-1 plasmids but differs with respect to incompatibility reactions, backbone restriction fragment profiles and sequence similarity since it gave negative results with the Couturier IncP-1 probe and the PCR test with trfA and korA primers (Table 3 ). This suggested that pQKH54 may represent a new branch of the IncP-1 family. Therefore its DNA sequence was determined as described in Methods, resulting in a complete genome of $69966 \mathrm{bp}$. The results are summarized in supplementary Table $S 1$, available with the online version of this paper. They confirmed that pQKH54 is indeed a typical IncP-1 plasmid on the basis that it carries all the key gene blocks of the IncP-1 group: the minimal replicon oriV and $\operatorname{trfA}$; the transfer origin oriT and associated transfer gene blocks tra and trb; the central control/ partitioning region korA-korB, and associated auxiliary operons $k f r$, kle and $k l c$. In general the promoter regions for these transcriptional units are typical of other IncP-1 plasmids and have obvious candidate operators for the IncP-1 global regulators, so it seems that the essential features of the regulatory network coordinating the genes for the basic plasmid functions of replication, stable inheritance and transfer are intact.

The $\mathrm{G}+\mathrm{C}$ content of the backbone is generally lower than for the other subgroups. If the trb region is excluded beyond the end of $\operatorname{trbL}$ (as the majority of these genes are unique to $\mathrm{pQKH} 54$ ), then the mean $\mathrm{G}+\mathrm{C}$ content of the backbone is $56.5 \mathrm{~mol} \%$, while it is $63.1 \mathrm{~mol} \%$ for RK2 (Pansegrau et al., 1994), $66.6 \mathrm{~mol} \%$ for R751 (Thorsted et al., 1998) and $62.0 \mathrm{~mol} \%$ for pEST4011 (Vedler et al., 2004). Thus it appears that $\mathrm{pQKH} 54$ has spent a considerable proportion of its recent evolutionary history in species with a lower $\mathrm{G}+\mathrm{C}$ content than the other branches of the IncP-1 family. While the overall structure of the backbone is conserved, there are several differences at the gene level, with genes common to the other IncP-1 groups either being deleted or replaced, or a novel gene inserted. In particular a new operon apparently comprising three small genes was identified upstream of, and reading towards, the $k l c$ region. The predicted promoter has KorC and KorA binding sites. Therefore this appears to be part of the IncP-1 KorA/C regulon for this plasmid. Of the kle region, only kleE remains, preceded by a new gene we have called $k l e H$. $k l c B$ is divided into two, and may be inactivated but may also simply provide the multiple functions associated with this region by way of two polypeptides rather than one, since there is a reasonable putative ribosome-binding site preceding the second ORF, $k l c B 2$. The downstream end of the trb operon is the most drastically changed. Starting from the promoter end of the operon, a new gene, $\operatorname{tr} b Q$, replaces trbM. $\operatorname{trbR}$ replaces $\operatorname{trb} \mathrm{O}$, with $\mathrm{O}_{\mathrm{B}} 7$ (typically at the start of trbO) being found at the end of trbR; a completely new terminus for the operon follows trbP, consisting of four or five genes. An IS element appears to have inactivated what may be the last gene. The novel genes in this region are generally of a lower $\mathrm{G}+\mathrm{C}$ content than the rest of the backbone. The tra operon carries only two new genes: a small potential regulator traP (on the basis of similarity to a phage regulatory protein) replacing traA, and a new gene traQ (that has no significant matches to anything in the database) between $\operatorname{traF}$ and $G$.

In the standard IncP-1 replication origin the iterons to which the Rep protein binds are organized as groups of 1,3 , 5 and 1 (in reverse), whereas in pQKH54 they are 1, 2, 5 and 2 (in reverse). Only the group of 5 is essential in RK2 (Thomas et al., 1981; Stalker et al., 1981). The number of auxiliary (non-essential) iterons is thus constant, which may be important since this has been shown to affect copy number control and incompatibility (Cross et al., 1984; Shah et al., 1995). The consensus sequence for the iterons has also changed - most significantly with the GC of the conserved TGAGGGGC motif being replaced by AT (Fig. 2), which may correlate with changes in the putative HTH motif of TrfA observed in pairwise alignments (data not shown).

The degree of DNA backbone sequence similarity to archetypal IncP-1 plasmids ranges from 69 and $67 \%$ (for RK2 and R751 respectively) for $2.3 \mathrm{~kb}$ of the central control region, through 65 and $66 \%$ for up to $15 \mathrm{~kb}$ of the trb region, to 62 and $64 \%$ for up to $15 \mathrm{~kb}$ of the tra region. This explains why detection of similarity to IncP-1 plasmids by the hybridization methods described above, which depends on base pairing to a defined DNA sequence, was only partially successful. The equivalent comparison between RK2 and R751 themselves showed 74, 73 and $70 \%$ sequence identity for these three regions. Phylogenetic analysis was carried out with the sequences of key genes (separately and pooled) from the regulon (Fig. 3), which showed clearly that $\mathrm{pQKH} 54$ is well separated from the IncP- $1 \alpha$ and $\beta$ groups. We therefore designated this plasmid as belonging to IncP- $1 \gamma$. The existence of this third group has already been referred to as 'personal communication' on the basis of conference presentations (Adamczyk \& Jagura-Burdzy, 2003). Because of this prior designation, another recently described IncP-1 plasmid, pEST4011, was designated IncP$1 \delta$ (Vedler et al., 2004) after the authors of that paper had compared their sequence with that of TrfA of pQKH54 supplied by us. One key point is that pQKH54 lacks evidence of the blocks of inverted repeats and restriction sites typical of the inter-backbone segment regions of IncP- $1 \beta$ plasmids 


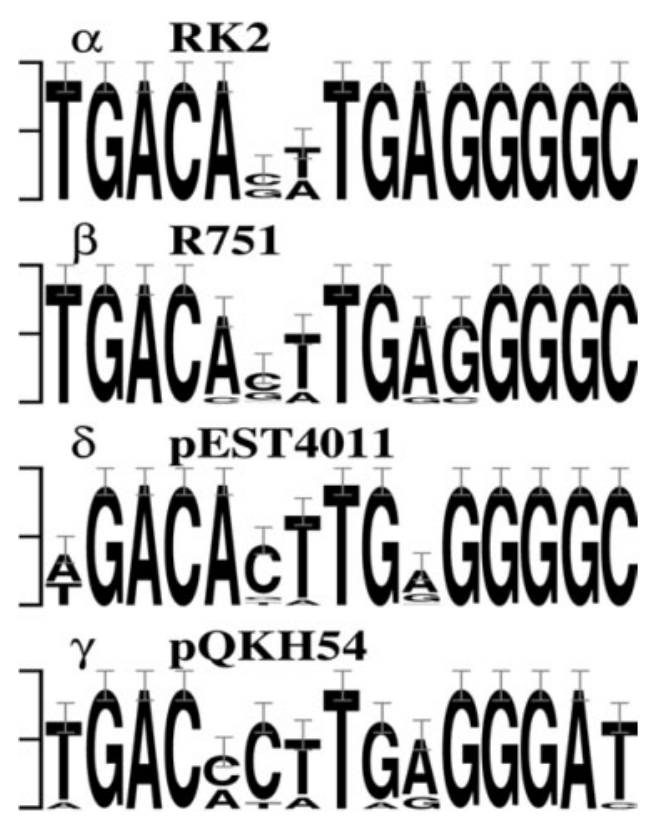

Fig. 2. Sequence logos of iterons for representatives of the four known IncP-1 subgroups. In a DNA sequence logo (Schneider \& Stephens, 1990; Crooks et al., 2004), the height of each base represents its conservation, with the information content of each position measured in bits. There are some minor variations between the groups, which may to some extent be due to neutral mutations. However, the consensus for pQKH54 shows a very clear difference of the last two bases. This suggests that this replicon is the most distant member of the IncP-1 group yet found, confirming the phylogenetic tree (Fig. 3), and possibly explaining the only partial incompatibility phenotype against RP4.
(Thorsted et al., 1998). Comparison with IncP- $1 \alpha$ and $\delta$ plasmids indicates that these repeats are confined to the $\beta$ group, which raises further questions about their origin and functional significance. It seems that they are a recent acquisition rather than an ancestral remnant.

\section{Genetic cargo carried by pQKH54}

There are two locations of IncP-1 plasmids where insertions into the backbone are typically found - between oriV and trfA and between the tra and trb operons. At these two areas, pQKH54 carries a total of around $27 \mathrm{~kb}$ of genetic load, or apparently non-backbone material. The mercury resistance of pQKH54 is encoded in a region between tra and $t r b$, in a cassette which is virtually identical to the mercury-resistance portion of Tn5053 (Kholodii et al., 1993,1995). The rest of this mobile element is mosaic in structure, with only a terminal match to Tn5053, suggesting that it is probably not self-transposable, being dependent on another element to provide the transposase function. Most remarkably, it contains a segment that is a very close match to part of $\operatorname{traC}$ of the IncP-1 $\beta$ plasmid R751. This appears to have been acquired by the transposon through an inexact transfer or recombination event from an ancestor of pADP-1 because this plasmid contains the appropriate conjunction of transposable element and IncP-1 backbone. A possible scheme for how this might have occurred is shown in Fig. 4. This proposed scheme is important because it suggests that IncP1 plasmids are sufficiently common in the environment as to have a reticulated history. Adjacent to this, in the mosaic region, are two more apparently complete genes. One of these shows some similarity to a sterol desaturase, while divergent from this is an AraC-family regulator (Gallegos et al., 1997).

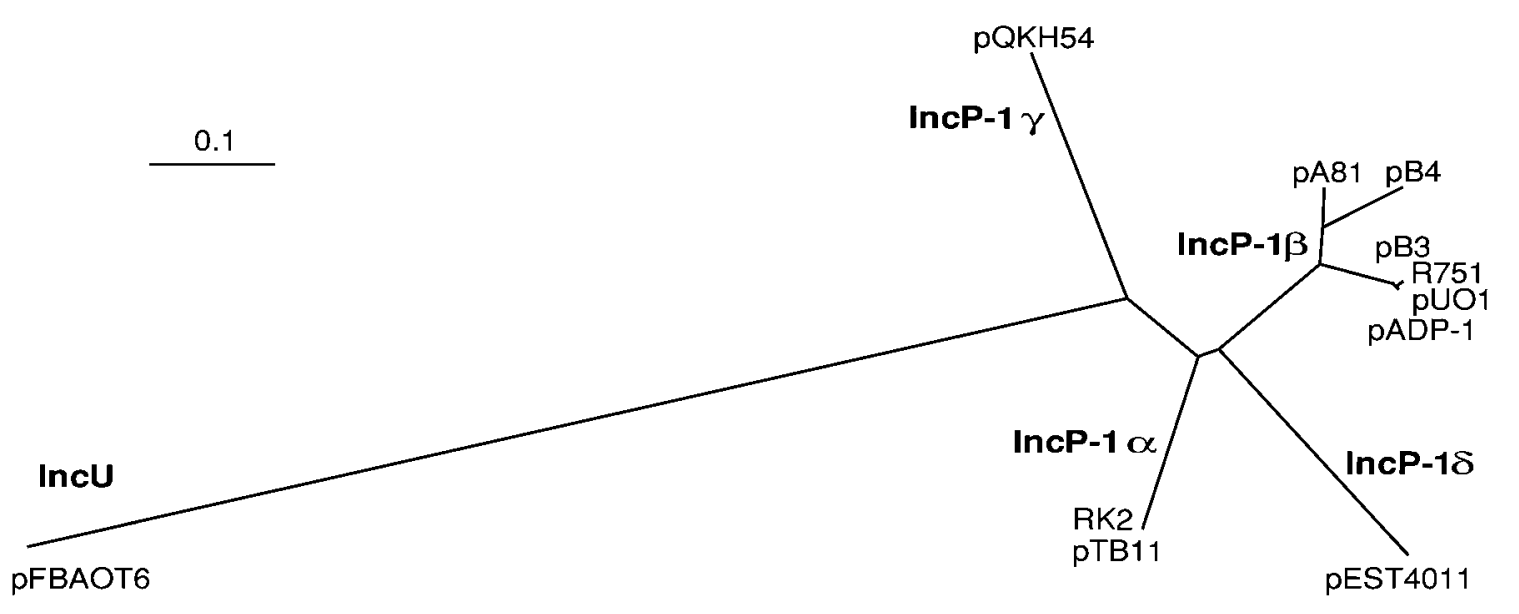

Fig. 3. Phylogenetic tree for IncP-1 plasmids currently available in public databases, using several proteins. Primary sequences of KorA, IncC2, KorB, KorC and KfrC (Upf54.4) were joined together and then aligned for IncP-1 plasmids plus a plasmid of the IncU group, which carries versions of these genes (Rhodes et al., 2004). The alignment was then used to build the phylogeny. The plasmids pB10 and pJP4 are not included since they appear to be chimeric products of recombination between pB4-like and R751 subgroup plasmids. 


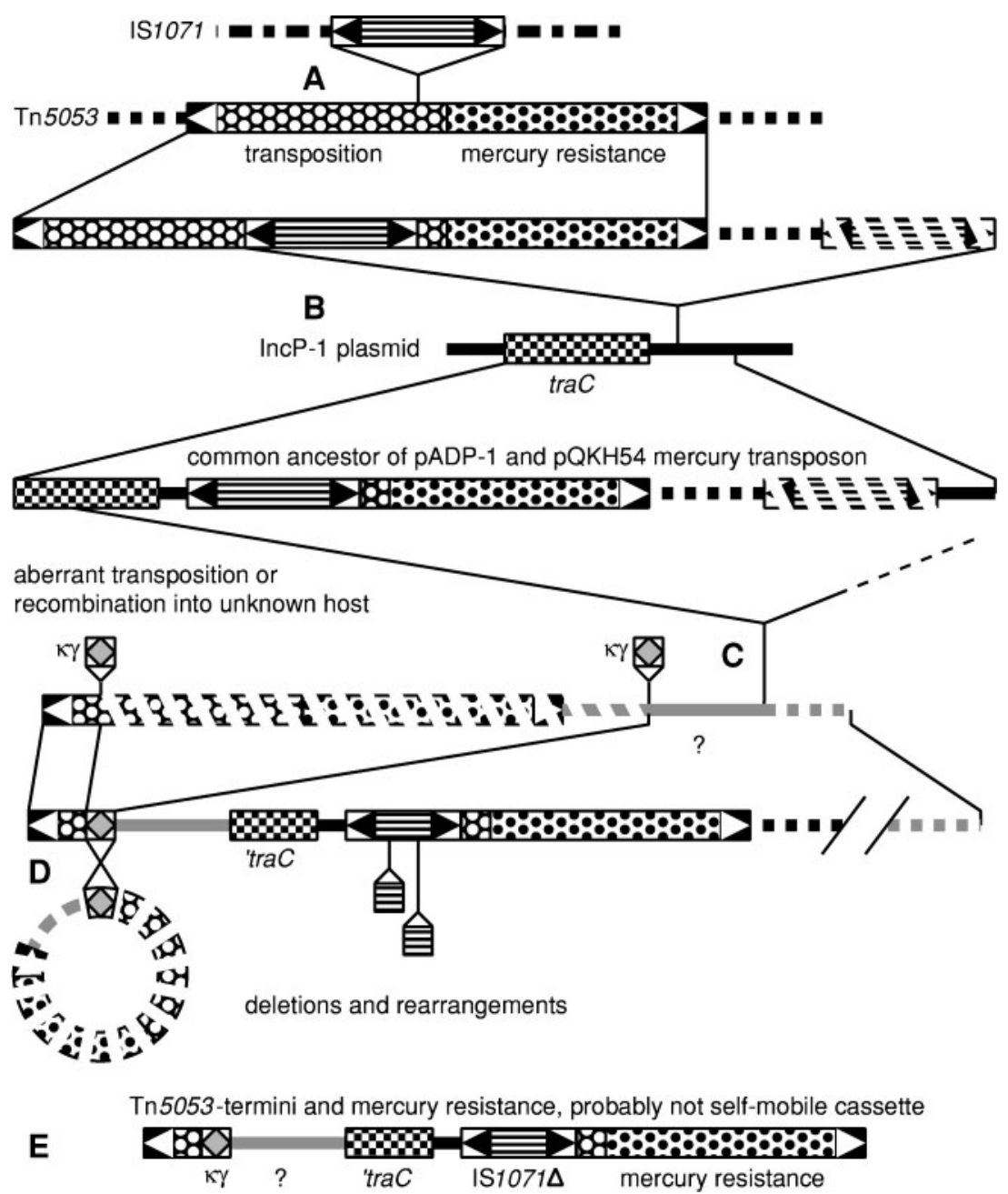

Fig. 4. Proposed lineage of the mercuryresistance element of pOKH54 explaining how it may have acquired a segment of IncP-1 backbone from an insertion as in pADP1, resulting in duplication of the traC region in PQKH54. Insertion or recombination events are shown as lines which converge to a point; lines indicating the resultant sequence do not. Mobile elements are shown as patterned boxes, as is gene traC. Terminal inverted repeats are shown as outward-facing triangles. Elements whose existence we have inferred are shown interrupted with diagonal stripes. Not to scale. The events are as follows. A. IS 1071 inserts into Tn5053. B. With a second copy of IS1071 it transposes into an IncP-1 $\beta$ plasmid like pADP1 adjacent to traC. C. Some sort of aberrant transposition or recombination brings heterologous DNA adjacent to traC. This DNA has or acquires another copy of Tn5053. D. The majority of this Tn5053 is deleted by homologous recombination between two copies of $\kappa \gamma$, a short 'parasitic' mobile element. Also, in either this or the preceding stage, two small deletions occur internal to IS1071. E. This leaves an element which can presumably be mobilized by $\operatorname{Tn} 5053$ transposase supplied in trans.

Nearby on one side of this transposon is an IS (ISUnCu3), while adjacent to this element is a Tn5053-related resolvase (Kholodii et al., 1993). This probably represents the remnants of a previous insertion. Between oriV and $\operatorname{trfA}$ there is a large segment of non-backbone material. Despite a region of homology including a two-component transposase on pB4 and an adjacent orphan gene, we were unable to identify matching termini for a transposon in this region. Neighbouring the $\mathrm{pB} 4$ homologous region is what appears to be an operon of genes and a divergently expressed AraC-family regulator.

\section{DISCUSSION}

This work has clearly shown that while all the plasmids studied are capable of conjugal transfer, not all are able to mobilize R300B efficiently and that there is not a consistent relationship between the efficiency of mobilization and that of retrotransfer of R300B. This confirms that retrotransfer is plasmid-specific and not a property of all conjugation systems (Guiney, 1993). However, at least for IncP-1 plasmids, the self-transmissible plasmid must move from the donor to the recipient before promoting retromobilization (Sia et al., 1996), so one would predict that retromobilization should obey the specificity rules of the TraG/VirD4 coupling protein family (Llosa et al., 2003). This does hold to the extent that plasmids that retromobilize efficiently are also generally good at mobilization, although it might be expected that mobilization frequency would be higher than retromobilization, which is not the case for pQM85 and pQM705 (Table 3). Therefore additional factors may be involved and, as with certain examples of mobilization, retrotransfer may reveal plasmid-pair specific properties (Willetts, 1981; Willetts \& Crowther, 1981). Where mobilization is efficient but retromobilization is not, it may be that surface exclusion, as suggested by Szpirer et al. (1999), can explain the results, so that pQM719 expresses proteins that cause the mating bridge to break down before the reverse transfer can occur. Detailed comparison of pQM719 with other IncP-1 plasmids may reveal differences in surface exclusion proteins that explain why it does not behave as expected from its apparent classification.

Reinforcing their importance as agents of retromobilization, the screening identified new IncP-1 plasmids, although not all of them initially gave clear-cut results. For pQM719, the 
mating technique used to examine plasmid incompatibility did not produce bidirectional incompatibility, which may be due to a second replicon in this plasmid. This would be consistent with pQM719 not being a completely typical IncP-1 plasmid, as already suggested in the previous paragraph. However, SphI restriction profiles, colony hybridization and the PCR suggest that both pQM719 and $\mathrm{pQKH} 6$ are related to the IncP- $1 \beta$ subgroup (Table 3 ) and have host ranges similar to the IncP-1 $\beta$ plasmids examined.

By contrast pQKH54 showed inconsistent plasmid grouping by the phenotypic and genotypic tests used, suggesting a degree of similarity with IncP-1 plasmids but insufficient sequence identity to react with the repP probe from the Couturier collection (Couturier et al., 1988). Similar problematic results were obtained for incompatibility testing of plasmids pQM705 and pQM85 (Table 3), indicating that although similarities may exist to the replication and maintenance genes of RP4, enough differences are present to allow maintenance of both systems after continuous growth in non-selective conditions. Explanations for such asymmetric incompatibility include the occurrence of a replicon fusion followed by deletion events to leave P-1 group incompatibility determinants on plasmids with alternative replication systems (Smith \& Thomas, 1989). Because the divergence of pQKH54 from RK2 and R751 made it difficult to use hybridization or PCR to assess its relatedness to the IncP-1 group, sequencing the whole genome proved an efficient analytical approach. The sequence revealed a surprisingly conserved IncP-1 backbone. It is therefore surprising that it showed efficient transfer but relatively inefficient retrotransfer (Table 3). The sequence may provide the basis for a detailed analysis of the surface exclusion functions as discussed above.

While pQKH54 clearly belongs to the IncP-1 family it is distinct from IncP-1 $\beta$ plasmids and appears to be somewhat less broad host range than $\mathrm{pQKH} 6$ and $\mathrm{pQM} 719$. This would also be consistent with the lower $\mathrm{G}+\mathrm{C}$ content of the genome since it suggests adaptation to a different group of hosts. The restriction map of pQKH54 predicted from the DNA sequence (data not shown) exhibited clustered regions of sites, coincident with the insertions of transposable elements or phenotypic determinants, a characteristic of all typical IncP-1 plasmids (Thomas \& Smith, 1987; Smith \& Thomas, 1989). Nevertheless pQKH54 does not possess the clusters of repeats associated with restriction sites (Thorsted et al., 1998; Heuer et al., 2004) that are now clearly associated only with IncP-1 $\beta$ plasmids. Despite the absence of these putative hot-spots for acquisition of transposable elements the only insertion into the backbone of pQKH54 occurs in one of these regions. The contiguous oriV-rep region confirms the nature of the ancestral backbone backbone as previously predicted by Smith et al. (1993) and first observed by Heuer et al. (2004).

Preliminary analysis for pQKH6 (data not shown) indicated one larger clustered region, containing both the mercury-resistance genes and genetic information homologous to the oriV region of RK2. This is consistent with the pQKH6 backbone being only interrupted in one place as found for the recently sequenced plasmids pJP4 (Trefault et al., 2004) and pB3 (Heuer et al., 2004) and as suggested for IncP-1 $\beta$ plasmids pSS50 and pSS60 (Burlage et al., 1990). While using PCR primers for $\operatorname{trf} A$ and korA did not identify any additional IncP-1 plasmids it did provide a simple basis to assess relatedness of backbone genes, showing that indeed pQKH6 and pSS50 are indistinguishable on the basis of the sequence determined.

The clearest phenotype conferred by pQKH54 is mercury resistance, which has been found previously in IncP- $1 \beta$ plasmids (Smith \& Thomas, 1987). The particular version of mer genes related to those in Tn501 is environmentally widespread, having been reported in 35-100\% of $\mathrm{Hg}^{\mathrm{r}}$ bacteria isolated from terrestrial environments (Osborn et al., 1993). In addition, the pQKH54 sequence identified four genes in two transposon-associated regions which may encode hitherto unsuspected phenotypic properties. The closest sequence database matches are a choline dehydrogenase, a hydratase, a taurine dioxygenase and a sterol desaturase (Supplementary Table S1). Both operons are divergently transcribed from AraC-family regulators. While we have not studied them experimentally, it is tempting to speculate that these may all be involved in catabolism of bile salts.

Overall the capacity of these aquatic plasmids to retrotransfer the small non-conjugative IncQ plasmid R300B and other IncQ plasmids (Hill et al., 1995) has important implications not only in the release of genetically engineered sequences, which are frequently encoded on non-conjugative cloning vectors (Bolivar et al., 1977), but also in terms of the role of plasmids in promoting horizontal gene transfer in natural microbial communities. This study shows that bacteria harbouring plasmids indigenous to freshwater biofilms are capable of capturing such genes and this can potentially occur from a wide range of bacterial hosts. Almost certainly completely new incompatibility groups have yet to be identified. Evidence for this comes from plasmid pQM85 studied here, which could capture R300B efficiently by retrotransfer, but could not be placed into any known retrotransfer proficient incompatibility group. Plasmids of the IncP-1 family appear to be the commonest for which good identification methods exist (Pukall et al., 1996; Smalla et al., 2000). Our data indicate that within natural aquatic systems a whole spectrum of IncP-1-like plasmids may be present with differing degrees of similarity to clinical IncP-1 plasmids, and probably adapted to particular hosts. This suggests a broad IncP-1 group rather than a closely defined one (Smith \& Thomas, 1989) and this point is reinforced by the recent report of a fourth IncP-1 subgroup designated IncP-1 $\delta$ (Vedler et al., 2004). Sequencing and classification of plasmids from a whole range of environmental sources is required to determine the true plasmid diversity found in nature and to determine 
whether new plasmids are related to known groups or represent completely new sequence families.

\section{ACKNOWLEDGEMENTS}

We thank Dr Mark Bailey for helpful advice and supplying the incompatibility probes used. The environmental sampling and initial analysis was supported by a grant from the Natural Environment Research Council. A.S.H. and K. J. and the majority of the DNA sequencing were supported by a project grant from The Wellcome Trust (06083). P. A. was supported by a BBSRC Quota studentship for training in research methods. A proportion of this work was carried out at Vlaamse Instelling voor Technologisch Onderzoek, Belgium, and we thank Dr Max Mergeay and Dr Roger Dijkmans for a productive visit.

\section{REFERENCES}

Adamczyk, M. \& Jagura-Burdzy, G. (2003). Spread and survival of promiscuous IncP-1 plasmids. Acta Biochimica Polonica 50, 425-453.

Austubel, F. M., Brent, R., Kingston, R. E., Moore, D. D., Seidman, J. D., Smith, J. A. \& Struhl, K. (1989). Current Protocols in Molecular Biology. New York: Wiley.

Bale, M. J., Fry, J. C. \& Day, M. J. (1987). Plasmid transfer between strains of Pseudomonas aeruginosa on membrane filters attached to river stones. J Gen Microbiol 133, 3099-3107.

Bale, M. J., Fry, J. C. \& Day, M. J. (1988). Transfer and occurrence of large mercury resistance plasmids in river epilithon. Appl Environ Microbiol 54, 972-978.

Barkay, T., Miller, S. M. \& Summers, A. O. (2003). Bacterial mercury resistance from atoms to ecosystems. FEMS Microbiol Revs 27, 355-384.

Barth, P. T. \& Grinter, N. J. (1974). Comparison of the deoxyribonucleic acid molecular weights and homologies of plasmids conferring linked resistance to streptomycin and sulphonamides. J Bacteriol 120, 618-630.

Birnboim, H. C. \& Doly, J. (1979). A rapid alkaline extraction procedure for screening recombinant plasmid DNA. Nucleic Acids Res 7, 1513-1523.

Blanco, G., Ramos, F., Medina, J. R., Gutierrez, J. C. \& Tortolero, M. (1991). Conjugal retrotransfer of chromosomal markers in Azotobacter vinelandii. Curr Microbiol 22, 241-246.

Bolivar, F., Rodriguez, R. L., Greene, P. J., Betlach, M. C., Heyneker, H. L. \& Boyer, H. W. (1977). Construction and characterization of new cloning vehicles. II. A multipurpose cloning system. Gene 2, 95-113.

Boronin, A. M. (1992). Diversity of Pseudomonas plasmids: to what extent? FEMS Microbiol Lett 100, 461-468.

Bradley, D. J. (1992). Gene transfer within epilithon of river stones. $\mathrm{PhD}$ thesis, UWCC, Cardiff, UK.

Burlage, R. S., Bemis, L. A., Layton, A. C., Sayler, G. S. \& Larimer, F. (1990). Comparative genetic organization of incompatibility group $P$ degradative plasmids. J Bacteriol 172, 6818-6825.

Couturier, M., Bex, F., Bergquist, P. L. \& Maas, W. K. (1988). Identification and classification of bacterial plasmids. Microbiol Rev 52, 375-395.

Cross, M. A., Warne, S. R. \& Thomas, C. M. (1986). Analysis of the vegetative replication origin of broad-host-range plasmid RK2 by transposon mutagenesis. Plasmid 15, 132-146.

Crooks, G. E., Hon, G., Chandonia, J. M. \& Brenner, S. E. (2004). WebLogo: a sequence logo generator. Genome Res 14, 1188-1190. which has full text at: http://weblogo.berkeley.edu//Crooks-2004-GRWebLogo.pdf.

Datta, N., Hedges, R. W., Shaw, E. J., Sykes, R. B. \& Richmond, M. H. (1971). Properties of an R-factor from Pseudomonas aeruginosa. J Bacteriol 108, 1244-1249.

Davey, R. B., Bird, P. I., Nikoletti, S. M., Praszkier, J. \& Pittard, J. (1984). The use of mini-gal plasmids for rapid incompatibility grouping of conjugative R plasmids. Plasmid 11, 234-242.

Devereux, J., Haeberli, P. \& Smithies, O. (1984). A comprehensive set of sequence-analysis programs for the VAX. Nucleic Acids Res 12, 387-395.

Don, R. H. \& Pemberton, J. M. (1981). Properties of six pesticide degradation plasmids isolated from Alcaligenes paradoxus and Alcaligenes eutrophus. J Bacteriol 145, 681-686.

Don, R. H. \& Pemberton, J. M. (1985). Genetic and physical map of the 2,4-dichlorophenoxyacetic acid degradative plasmid pJP4. J Bacteriol 161, 466-468.

Droge, M., Puhler, A. \& Selbitschka, W. (2000). Phenotypic and molecular characterization of conjugative antibiotic resistance plasmids isolated from bacterial communities of activated sludge. Mol Gen Genet 263, 471-482.

Ewing, B. \& Green, P. (1998). Base-calling of automated sequencer traces using phred. II. Error probabilities. Genome Res 8, 186-194.

Ewing, B., Hillier, L., Wendl, M. C. \& Green, P. (1998). Base-calling of automated sequencer traces using phred. I. Accuracy assessment. Genome Res 8, 175-185.

Fry, J. C. \& Day, M. J. (1990). Plasmid transfer in the epilithon. In Bacterial Genetics in Natural Environments, pp. 55-80. Edited by J. C. Fry \& M. J. Day. London: Chapman \& Hall.

Gallegos, M. T., Schleif, R., Bairoch, A., Hofmann, K. \& Ramos, J. L. (1997). AraC/XylS family of transcriptional regulators. Microbiol Mol Biol Rev 61, 393-410.

Gomis-Ruth, F. X., de la Cruz, F. \& Coll, M. (2002). Structure and role of coupling proteins in conjugal DNA transfer. Res Microbiol 153, 199-204.

Gordon, D., Abajian, C. \& Green, P. (1998). Consed: a graphical tool for sequence finishing. Genome Res 8, 195-202.

Gordon, D., Desmarais, C. \& Green, P. (2001). Automated finishing with Autofinish. Genome Res 11, 614-625.

Guiney, D. G. (1993). Broad host range conjugative and mobilizable plasmids in Gram-negative bacteria. In Bacterial Conjugation, pp. 75-103. Edited by D. B. Clewell. New York: Plenum.

Hanahan, D. (1983). Studies on transformation of Escherichia coli with plasmids. J Mol Biol 166, 557-580.

Hedges, R. W. \& Matthew, M. (1979). Acquisition by Escherichia coli of plasmid-borne $\beta$-lactamases normally confined to Pseudomonas spp. Plasmid 2, 269-278.

Heinemann, J. A. \& Ankenbauer, R. G. (1993a). Retrotransfer in Escherichia coli conjugation: bidirectional exchange or de novo mating. J Bacteriol 175, 583-588.

Heinemann, J. A. \& Ankenbauer, R. G. (1993b). Retrotransfer of IncP plasmid R751 from Escherichia coli maxicells - evidence for the genetic sufficiency of self-transferable plasmids for bacterial conjugation. Mol Microbiol 10, 57-62.

Heinemann, J. A. \& Sprague, G. F. (1989). Bacterial conjugative plasmids mobilize DNA transfer between bacteria and yeast. Nature 340, 205-209.

Heuer, H., Szczepanowski, R., Schneiker, S., Puhler, A., Top, E. M. \& Schluter, A. (2004). The complete sequences of plasmids $\mathrm{pB} 2$ and $\mathrm{pB} 3$ provide evidence for a recent ancestor of the IncP-1 $\beta$ group without any accessory genes. Microbiology 150, 3591-3599. 
Hill, K. E., Weightman, A. J. \& Fry, J. C. (1992). Isolation and screening of plasmids from the epilithon which mobilize recombinant plasmid pD10. Appl Environ Microbiol 58, 1292-1300.

Hill, K. E., Fry, J. C., Weightman, A. J., Day, M. J., Bradley, D. J. \& Cousland, B. (1995). Retrotransfer of IncP1-like plasmids from aquatic bacteria. Lett Appl Microbiol 20, 317-322.

Hooper, S. W., Dockendorff, T. C. \& Sayler, G. S. (1989). Characteristics and restriction analysis of the 4-chlorobiphenyl catabolic plasmid, pSS50. Appl Environ Microbiol 55, 1286-1288.

Jacob, A. E. (1977). Plasmids studied in Escherichia coli and other enteric bacteria. In DNA Insertion Elements, Plasmids and Episomes, pp. 607-638. Edited by A. I. Bukhari, J. A. Shapiro \& S. L. Adhya. Cold Spring Habor, NY: Cold Spring Habor Laboratory.

Jeenes, D. J. \& Williams, P. A. (1982). Excision and integration of degradative genes from TOL plasmid pWW0. J Bacteriol 150, 188-194.

Jobanputra, R. S. \& Datta, N. (1974). Trimethoprim R factors in enterobacteria from clinical specimens. J Med Microbiol 7, 169-177. Kado, C. I. \& Liu, S. T. (1981). Rapid procedure for detection and isolation of large and small plasmids. J Bacteriol 145, 1365-1373.

Kholodii, G. Y., Yurieva, O. V., Lomovskaya, O. L., Gorlenko, Z., Mindlin, S. Z. \& Nikiforov, V. G. (1993). Tn5053, a mercury resistance transposon with integron's ends. J Mol Biol 230, 1103-1107.

Kholodii, G. Y., Mindlin, S. Z., Bass, I. A., Yurieva, O. V., Minakhina, S. V. \& Nikiforov, V. G. (1995). Four genes, two ends, and a res region are involved in transposition of Tn5053: a paradigm for a novel family of transposons carrying either a mer operon or an integron. Mol Microbiol 17, 1189-1200.

Kittell, B. \& Helinski, D. R. (1993). Plasmid incompatibility and replication control. In Bacterial Conjugation, pp. 223-242. Edited by D. B. Clewell. New York: Plenum.

Kreps, S., Ferino, F., Mosrin, C., Gerits, J., Mergeay, M. \& Thuriaux, P. (1990). Conjugative transfer and autonomous replication of the promiscuous IncQ plasmid in the cyanobacterium Synechocystis PCC 6803. Mol Gen Genet 221, 129-133.

Llosa, M., Zunzunegui, S. \& de la Cruz, F. (2003). Conjugative coupling proteins interact with cognate and heterologous VirB10-like proteins while exhibiting specificity for cognate relaxosomes. Proc Natl Acad Sci U S A 100, 10465-10470.

McClure, N. C., Weightman, A. J. \& Fry, J. C. (1989). Survival of Pseudomonas putida UWC1 containing cloned catabolic genes in a model activated sludge unit. Appl Environ Microbiol 55, 2627-2634.

McClure, N. C., Saint, C. P., Fry, J. C. \& Weightman, A. J. (1990). The Construction of Broad Host Range Genetic Markers and their Use in Monitoring the Release of Catabolic GEMS to Aquatic Environments. Copenhagen, Denmark: Proceedings of the 5th European Congress on Biotechnology.

Mergeay, M., Lejeune, P., Thiry, G. \& Faelen, M. (1985). Back transfer: a property of some broad host range plasmids. In Plasmids in Bacteria, p. 942 . Edited by D. R. Helinski, S. N. Cohen, D. B. Clewell, D. A. Jackson \& A. Hollaender. New York \& London: Plenum.

Mergeay, M., Lejeune, P., Sadouk, A., Gerits, J. \& Fabry, L. (1987). Shuttle transfer (or retrotransfer) of chromosomal markers mediated by plasmid pULB113. Mol Gen Genet 209, 61-70.

Mergeay, M., Springael, D. \& Top, E. (1990). Gene transfer in polluted soils. In Bacterial Genetics in Natural Environments, pp. 152-171. Edited by J. C. Fry \& M. J. Day. London: Chapman \& Hall.

Norrander, J., Kempe, T. \& Messing, J. (1983). Construction of improved M13 vectors using oligodeoxynucleotide-directed mutagenesis. Gene 26, 101-106.
Novick, R. P. (1987). Plasmid incompatibility. Microbiol Rev 51, 381-395.

Osborn, A. M., Bruce, K. D., Strike, P. \& Ritchie, D. A. (1993). Polymerase chain reaction-restriction fragment length polymorphism analysis shows divergence among mer determinants from Gramnegative soil bacteria indistinguishable by DNA-DNA hybridization. Appl Environ Microbiol 59, 4024-4030.

Pansegrau, W., Lanka, E., Barth, P. T. \& 7 other authors (1994). Complete nucleotide sequence of Birmingham IncP-alpha plasmids compilation and comparative analysis. J Mol Biol 239, 623-663.

Perkins, C. D., Davidson, M. A., Day, M. J. \& Fry, J. C. (1994). Retrotransfer kinetics of R300B by pQKH6, a conjugative plasmid from river epilithon. FEMS Microbiol Ecol 15, 33-44.

Powell, B., Mergeay, M. \& Christofi, N. (1989). Transfer of broad host-range plasmids to sulphate-reducing bacteria. FEMS Microbiol Lett 59, 269-274.

Pukall, R., Tschape, H. \& Smalla, K. (1996). Monitoring the spread of broad host and narrow host range plasmids in soil microcosms. FEMS Microbiol Ecol 20, 53-66.

Ramos-González, M., Ramos-Díaz, M. \& Ramos, J. L. (1994). Chromosomal gene capture mediated by the Pseudomonas putida TOL catabolic plasmid. J Bacteriol 176, 4635-4641.

Rhodes, G., Parkhill, J., Bird, C., Ambrose, K., Jones, M. C., Huys, G., Swings, J. \& Pickup, R. W. (2004). Complete nucleotide sequence of the conjugative tetracycline resistance plasmid pFBAOT6, a member of a group of IncU plasmids with global ubiquity. Appl Environ Microbiol 70, 7497-7510.

Rochelle, P. A., Fry, J. C., Day, M. J. \& Bale, M. J. (1985). An accurate method for estimating sizes of small and large plasmids and DNA fragments by gel electrophoresis. J Gen Microbiol 132, 53-59.

Rochelle, P. A., Fry, J. C. \& Day, M. J. (1989). Factors affecting conjugal transfer of plasmids encoding mercury resistance from pure cultures and mixed natural suspensions of epilithic bacteria. J Gen Microbiol 135, 409-424.

Ronchel, M. C., Ramos-Diaz, M. A. \& Ramos, J. L. (2000) Retrotransfer of DNA in the rhizosphere. Environ Microbiol 2, 319-323.

Rosenberg, C. \& Huguet, T. (1984). The pATC58 plasmid of Agrobacterium tumefaciens is not essential for tumor induction. Mol Gen Genet 196, 533-536.

Rutherford, K., Parkhill, J., Crook, J., Horsnell, T., Rice, P., Rajandream, M.-A. \& Barrell, B. (2000). Artemis: sequence visualisation and annotation. Bioinformatics 16, 944-945.

Sambrook, J., Fritsch, E. F. \& Manniatis, T. (1989). Molecular Cloning: a Laboratory Manual. Cold Spring Harbor, NY: Cold Spring Harbor Laboratory.

Schneider, T. D. \& Stephens, R. M. (1990). Sequence logos: a new way to display consensus sequences. Nucleic Acids Res 18, 6097-6100.

Shah, D. S., Cross, M. A., Porter, D. \& Thomas, C. M. (1995). Dissection of the core and auxiliary sequences in the vegetative replication origin of promiscuous plasmid RK2. J Mol Biol 254, 608-622.

Sia, E. A., Kuehner, D. M. \& Figurski, D. H. (1996). Mechanism of retrotransfer in conjugation: prior transfer of the conjugative plasmid is required. J Bacteriol 178, 1457-1464.

Smalla, K., Krogerrecklenfort, E., Heuer, H. \& 21 other authors (2000). PCR-based detection of mobile genetic elements in total community DNA. Microbiology 146, 1256-1257.

Smit, E., Venne, D. \& van Elsas, J. D. (1993). Mobilization of a recombinant IncQ plasmid between bacteria on agar and in soil via cotransfer or retrotransfer. Appl Environ Microbiol 59, 2257-2263. 
Smith, C. A. \& Thomas, C. M. (1987). Comparison of the organization of the genomes of phenotypically diverse plasmids of incompatibility group-P - members of the IncP-beta-sub-group are closely related. Mol Gen Genet 206, 419-427.

Smith, C. A. \& Thomas, C. M. (1989). Relationships and evolution of IncP plasmids. In Promiscuous Plasmids of Gram-negative Bacteria, pp. 57-77. Edited by C. M. Thomas. London: Academic Press.

Smith, C. A., Pinkney, M., Guiney, D. G. \& Thomas, C. M. (1993). The ancestral IncP replication system consisted of contiguous oriV and trfA segments as deduced from a comparison of the nucleotide sequences of diverse IncP plasmids. J Gen Microbiol 139, 1761-1766.

Stalker, D. M., Thomas, C. M. \& Helinski, D. R. (1981). Nucleotidesequence of the region of the origin of replication of the broad host range plasmid RK2. Mol Gen Genet 181, 8-12.

Stanisich, V. A. (1988). Identification and analysis of plasmids at the genetic level. In Plasmid Technology, pp. 11-47. Edited by J. Grinsted \& P. M. Bennett. London: Academic Press.

Szpirer, C., Top, E., Couturier, M. \& Mergeay, M. (1999). Retrotransfer or gene capture: a feature of conjugative plasmids, with ecological and evolutionary significance. Microbiology 145, 3321-3329.

Thiry, G., Mergeay, M. \& Faelen, M. (1984). Back-mobilisation of $\mathrm{Tra}^{-} \mathrm{Mob}^{+}$plasmids mediated by various IncM, IncN and IncP1 plasmids. Arch Intern Physiol Biochem 92, 64-65.

Thomas, C. M. \& Smith, C. A. (1987). Incompatibility group P plasmids: genetics, evolution, and use in genetic manipulation. Annu Rev Microbiol 41, 77-101.

Thomas, C. M. \& Thorsted, P. B. (1994). PCR probes for promiscuous plasmids. Microbiology 140, 1.

Thomas, C. M., Stalker, D. M. \& Helinski, D. R. (1981). Replication and Incompatibility properties of segments of the origin region of replication of the broad host range plasmid RK2. Mol Gen Genet 181, $1-7$.

Thorsted, P. A., Macartney, D. P., Akhtar, P. \& 9 other authors (1998). Complete sequence of the IncP beta plasmid R751: implications for evolution and organisation of the IncP backbone. J Mol Biol 282, 969-990.

Top, E., Vanrolleghem, P., Mergeay, M. \& Verstraete, W. (1992). Determination of the mechanism of retrotransfer by mechanistic mathematical modelling. J Bacteriol 174, 5953-5960.

Top, E., De Rore, H., Collard, J., Gellens, V., Slobodkina, G., Verstraete, W. \& Mergeay, M. (1995). Retromobilization of heavy metal resistance genes in unpolluted and heavy metal polluted soil. FEMS Microbiol Ecol 18, 191-203.

Trefault, N., De la Iglesia, R., Molina, A. M., Manzano, M., Ledger, T., Perez-Pantoja, D., Sanchez, M. A., Stuardo, M. \& Gonzalez, B. (2004). Genetic organization of the catabolic plasmid pJP4 from Ralstonia eutropha JMP134(pJP4) reveals mechanisms of adaptation to chloroaromatic pollutants and evolution of specialized chloroaromatic degradation pathways. Environ Microbiol 6, 655-668.

Trieu-Cuot, P., Carlier, C., Martin, P. \& Courvalin, P. (1987). Plasmid transfer by conjugation from Escherichia coil to gram-positive bacteria. FEMS Microbiol Lett 48, 289-294.

Vedler, E. M., Vahter, A. \& Heinaru, A. (2004). The completely sequenced plasmid pEST4011 contains a novel IncP1 backbone and a catabolic transposon harbouring $t f d$ genes for 2,4-dichlorophenoxyacetic acid degradation. J Bacteriol 186, 7161-7174.

Wheatcroft, R. \& Williams, P. A. (1981). Rapid methods for the study of both stable and unstable plasmids in Pseudomonas. J Gen Microbiol 124, 433-437.

Willetts, N. (1981). Sites and systems for conjugal DNA transfer in bacteria. In Molecular Biology, Pathogenicity and Ecology of Bacterial Plasmids, pp. 207-215. Edited by S. T. Levy, R. C. Clowes \& E. L. Koenig. New York: Plenum.

Willetts, N. \& Crowther, C. (1981). Mobilization of the nonconjugative IncQ plasmid RSF1010. Genet Res 37, 311-316.

Wlodarczyk, M. \& Piechucka, E. (1995). Conjugal transfer of plasmid and chromosomal markers between strains of Thiobacillus versutus. Curr Microbiol 30, 185-191. 